\title{
INFLUENCE OF MEAT TYPE, SEX AND STORAGE TIME ON FATTY ACID PROFILE OF FREE RANGE DALMATIAN TURKEY
}

\author{
Maja Mauric ${ }^{1}$, Kristina Starcevic ${ }^{1}$, Sven Mencik ${ }^{1}$, \\ Mario Ostovic ${ }^{2}$, Anamaria Ekert Kabalin ${ }^{1}$ \\ ${ }^{1}$ Department of Animal Husbandry, Faculty of Veterinary Medicine, \\ University of Zagreb, Zagreb, Croatia \\ ${ }^{2}$ Department of Animal Behavior and Animal Welfare, Faculty of Veterinary \\ Medicine, University of Zagreb, Zagreb, Croatia \\ Received 26 January 2016; Received in revised form 25 March 2016; Accepted 31 March 2016
}

\begin{abstract}
Dalmatian turkey is a slow growing breed kept in free range systems. It is a type of "old fashioned poultry" whose meat is present on the market and accepted by consumers. However, no information about its meat quality and fatty acid profile is available. The chemical composition of the meat was influenced by gender and meat type and these differences could be important from the consumer's point of view. Fatty acid composition was characterized by the predominance of n 6 fatty acids, especially $\mathrm{C} 18: 2 \mathrm{n} 6$ and a high $\mathrm{n} 6 / \mathrm{n} 3$ ratio. Increased time of storage strongly reduced the long chain polyunsaturated fatty acid (LC PUFA) and increased atherogenicity and thrombogenicity indices (AI and TI) in thigh tissue. The content of beneficial n3 PUFA was influenced by meat type, with lower values of C18:3n 3 and higher values of LC PUFA in the breast compared to the thighs. The potential intake of LC PUFA of comercial turkey in the human diet was lower in comparison to poultry fed with complete feed mixtures. An interesting fact was the higher DHA values in comparison with DPA values in breast tissue, which is characteristic of old poultry breeds. The Dalmatian turkey is a highly valued traditional product and an important archaic breed for gene preservation and biodiversity. Nevertheless, Dalmatian turkey meat could be even further improved by minimal dietary manipulation to become a product with additional health promoting effects.
\end{abstract}

Key words: Dalmatian turkey, fatty acid, meat quality, biodiversity

\section{INTRODUCTION}

Consumers of animal products are becoming more aware of the benefits of a balanced diet for their health (1). Poultry meat is highly valued for its nutritional properties: low fat content and less saturated fatty acid than most ruminant edible tissues. Turkey is one of the leanest types of poultry as well as a good source of protein and minerals, such as sodium, potassium and iron, and it is part of the regular diet in many countries (1). Other

\footnotetext{
Corresponding author: Dr. Kristina Starčević, $\mathrm{PhD}$

E-mail address: kstarcevic@vef.hr

Present address: Faculty of Veterinary Medicine

University of Zagreb, 10000 Zagreb, Croatia

Phone: ++385-1-2390139; Fax: ++385-1-2441390

Copyright: (C) 2016 Mauric M. This is an open-access article published under the terms of the Creative Commons Attribution License which permits unrestricted use, distribution, and reproduction in any medium, provided the original author and source are credited. Competing Interests: The authors have declared that no competing interests exist.

Available Online First: 8 April 2016

Published on: 15 October 2016

http://dx.doi.org/10.1515/macvetrev-2016-008
}

important factors responsible for its growing place on the market are its neutral taste and smooth texture (2).

Recently, numerous studies have been performed to investigate the fatty acid composition of poultry meat reared on commercial farms $(3,4)$. The meat fatty acid composition of poultry depends on the poultry diet, rearing practices and breed (5) and these factors can serve as a tool for manipulation of the fatty acids content. Given the beneficial effects of $n 3$ fatty acids on human health, research has been focused on offering consumers meat enriched with n3 fatty acids $(5,6)$. Nevertheless, lipid oxidation of unsaturated fatty acids is a major cause of meat quality deterioration, which lowers the functional, sensory and nutritive value of meat products, and therefore, consumer acceptability (7).

Very few data on meat fatty acid composition of indigenous breeds have been reported in the literature, despite the well-known fact that meat from free range bred animals is often perceived to be healthier by the public (8). The Dalmatian turkey 
is an indigenous type of poultry in the Dalmatian region of Croatia (9). This form of turkey has been developed over the centuries as a result of the local harsh conditions (9). Due to its adaptation to the surroundings and its disease resistance, the Dalmatian turkey could be considered as "old fashioned poultry" of the Mediterranean climate and was a part of a project "Dalmatian Turkey phenotypic parameters and ecological characteristics of the area" of the Ministry of Agriculture, Fisheries and Rural Development of the Republic of Croatia for the preservation of autochthonous Croatian breeds of domestic animals.

Although this breed of turkey is important for the local community and gene preservation programs, no data on the chemical composition and fatty acid profile of the free-range bred Dalmatian turkey meat exists. Accordingly, this study was undertaken with the objective to investigate the growth performance, meat chemical composition and fatty acid profile of edible meat, as well as to assess the potential of this turkey breed for further improvement via dietary and rearing manipulation. There are limited numbers of studies of frozen storage (10) available in the literature on lipid oxidation in turkey meat and the impact on the fatty acid profile; therefore we investigated the effect of long frozen storage (6 month) on the fatty acid profile in turkey thigh and breast meat.

\section{MATERIAL AND METHODS}

Animals, growth performance and body parts measurements

In the present study, 40 turkeys - 20 males and 20 females were used. The study was conducted under

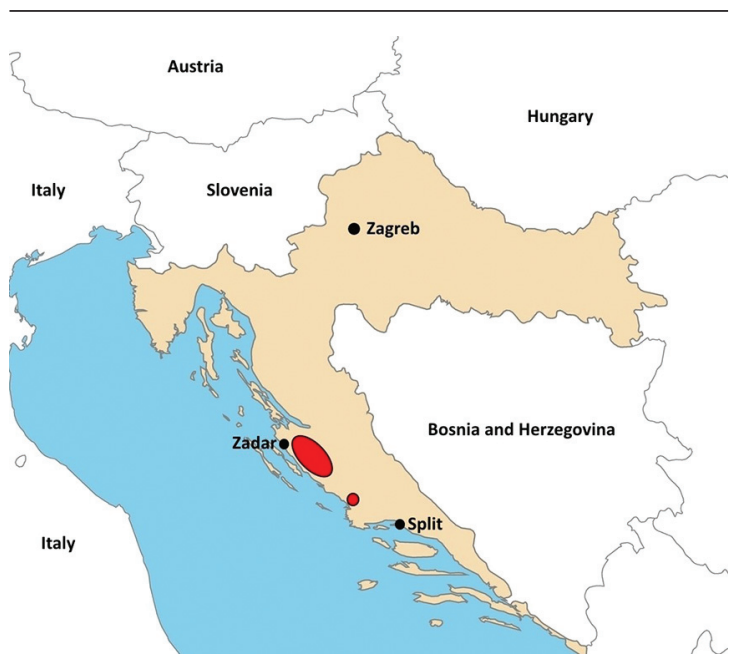

Figure 1. Geographical location (red circles) of experimental farms in the Dalmatian hinterland the usual conditions of rearing and management of flocks in the local communities of the Dalmatian hinterland (Fig. 1).

The feeding program consisted of a standard turkey starter during the first two months and afterwards the diets of the free range birds consisted of scarce pasture, various cereals and vegetable remains. During the experiment, the birds were individually weighed. Body weight (BW) was recorded at the beginning, after 16 weeks and then every six weeks till the end of the study which lasted for 28 weeks. The animals were stunned at 28 weeks of age, slaughtered, bled and plucked in a commercial slaughterhouse. The carcasses were chilled at $4^{\circ} \mathrm{C}$ for $24 \mathrm{~h}$. The day after, the left sides of the carcasses were quartered according to the Hahn and Spindler (11) cutting method. The composition of each part was calculated as the weight of each tissue component per unit sum of all the dissected components (12). The samples of breast $(m$. pectoralis superficialis) and thigh muscle ( $m$. iliotibialis cranialis) were then split in two groups, one was frozen at $-18{ }^{\circ} \mathrm{C}$ and kept for 6 months and the second was frozen at $-80^{\circ} \mathrm{C}$ and analyzed within three days.

Determination of chemical composition of breast and thigh muscle

The tissue samples of breast ( $m$. pectoralis superficialis) and thigh muscle ( $m$. iliotibialis cranialis) were minced through a $3.0 \mathrm{~mm}$ plate using a kitchen-type mincer to obtain homogeneous samples. Protein, ash and moisture contents were estimated according to recommended methods (13). Two replicates of each sample were analyzed and the mean value was used in the data analyses.

\section{Gas chromatography analysis}

Muscle fat content for fatty acid analyses was extracted with a chloroform and methanol mixture $(2: 1, \mathrm{v} / \mathrm{v})(14)$ at 0 month and six months. The fatty acids were analyzed as their methyl esters, after transesterification with a $2 \mathrm{M} \mathrm{KOH}$ solution in methanol. Analysis of fatty acid was performed on GC2010Plus Gas Chromatograph (Shimadzu, Japan) equipped with a flame-ionization detector. The capillary column used was ZB WAX (Phenomenex, Torrance, CA, USA), $30 \mathrm{~m} \times 0.25 \mathrm{~mm}$ with film thickness of $0.25 \mu \mathrm{m}$. The injector temperature was set to $250^{\circ} \mathrm{C}$ and $1 \mu \mathrm{l}$ of each sample was injected with a split ratio 1:15. Helium was used as the carrier gas and the detector temperature was set at $300^{\circ} \mathrm{C}$. The oven program was as follows: the initial temperature was set at $60^{\circ} \mathrm{C}$ for $2 \mathrm{~min}$, then increased at the rate of $13^{\circ} \mathrm{C} / \mathrm{min}$ up to $150^{\circ} \mathrm{C}$, then increased at $2^{\circ} \mathrm{C} / \mathrm{min}$ up to $220^{\circ} \mathrm{C}$, increased at $2^{\circ} \mathrm{C} / \mathrm{min}$ 


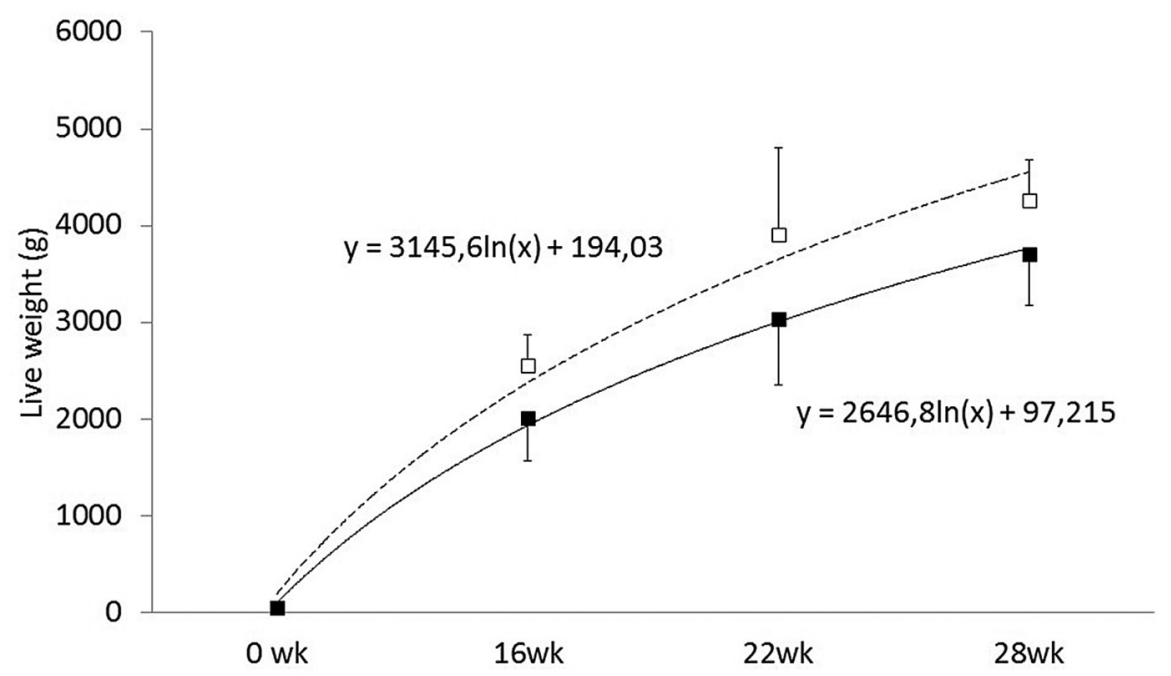

Figure 2. Growth curve of male and female experimental turkeys (mean and SD), $\square$ Male, Female, - Male $(\mathrm{N}=20),-$ Female $(\mathrm{N}=20)$

to $240^{\circ} \mathrm{C}$ and held at $10^{\circ} \mathrm{C}$. All the experimental measurements were repeated three times and the average values reported. The quantification was carried out through area normalization with an external standard mixture of fatty acid methyl esters (Sigma-Aldrich, Steinheim, Germany). Fatty acid composition was calculated as a percentage of each individual fatty acid relative to total fatty acids.

\section{Atherogenicity and thrombogenicity indices}

Indices of atherogenicity (AI) and thrombogenicity (TI) were calculated as the relationship between the major saturated fatty acids and the main classes of unsaturated fatty acids. The following equations were applied (15):

$$
\begin{gathered}
\text { Atherogenicity index }(\mathrm{AI})=\frac{\mathrm{C} 12: 0+4 \times \mathrm{C} 16: 0+\mathrm{C} 18: 0}{[\text { MUFA }+\mathrm{n} 6+\mathrm{n} 3]} \\
\text { Thrombogenicity index }(\mathrm{TI})=\frac{\mathrm{C} 14: 0+\mathrm{C} 16: 0+\mathrm{C} 18: 0}{0.5 \times \text { MUFA } 0.5 \times \mathrm{n} 6+3 \times \mathrm{n} 3+\frac{\mathrm{n} s}{\mathrm{n} 6}}
\end{gathered}
$$

Statistical analysis

Data was analyzed using the Statistical software (STATISTICA 2010 program, Tulsa, OK, USA).
All results were presented as means and standard deviation. The model included sex (female or male), meat type (breast or thigh) and time of storage $(0$ or 6 months) as factors, and the interaction between these three factors. Statistical differences among the groups were tested by analysis of variance (ANOVA), and Tukey's test was applied in order to determine statistical differences between group means. Significance was determined at $\mathrm{P}<0.05$.

\section{RESULTS}

The growth performance of indigenous Dalmatian turkey is presented in Figure 2. The birds were regularly monitored by a local veterinarian. During the trial, no deleterious effects on health were observed.

The final live weight for the male and female animals was $4.3 \pm 0.4 \mathrm{~kg}$ and $3.7 \pm 0.5 \mathrm{~kg}$, respectively. The dressing percentage, drumstick, thigh and breast weight are given in Table 1 .

Table 1. Body parts measurements

\begin{tabular}{lcccccccccc}
\hline & \multicolumn{4}{c}{ Female } \\
\cline { 2 - 11 } & Mean & $\mathbf{N}$ & SD & Min & Max & Mean & N & SD & Min & Max \\
\hline Dressing percentage (\%) & 71.2 & 20 & 3.5 & 64.8 & 76.0 & 70.4 & 20 & 4.9 & 62.0 & 75.2 \\
Drumstick (g) & 174.9 & 20 & 12.2 & 157.0 & 190.0 & 270.7 & 20 & 26.0 & 233.0 & 326.0 \\
Thigh (g) & 199.9 & 20 & 21.5 & 156.0 & 224.0 & 286.1 & 20 & 26.0 & 249.0 & 328.0 \\
Breast (g) & 749.2 & 20 & 103.7 & 588.0 & 890.0 & 1253.4 & 20 & 267.8 & 778.0 & 1710.0 \\
\hline
\end{tabular}


Weight of male drumstick, thigh and breast were higher than of female ones. The aforementioned is in accordance with Ekert Kabalin et al. (8).

The influence of gender on the chemical composition of turkey meat was noted for dry matter (DM) $(\mathrm{P}<0.001)$, protein $(\mathrm{P}<0.001)$ and fat content $(\mathrm{P}<0.05)$ with female turkeys having higher $\mathrm{DM}$ and protein and lower fat content (Table 2). Meat type also influenced DM $(\mathrm{P}<0.01)$, protein $(\mathrm{P}<0.001)$ and fat content $(\mathrm{P}<0.001)$. Higher content of DM and protein and lower of fat were found in breast meat compared to thigh meat. The interaction between sex and meat type was found only for fat content $(\mathrm{P}<0.01)$. No differences were found for any of the mentioned factors in ash content (Table 2).
After being stored for 6 months, C15:0 $(\mathrm{P}<0.05), \quad \mathrm{C} 15: 1 \quad(\mathrm{P}<0.001), \quad \mathrm{C} 16: 0 \quad(\mathrm{P}<0.001)$, C17:1 $(\mathrm{P}<0.01), \mathrm{C} 18: 0(\mathrm{P}<0.01), \mathrm{C} 20: 2(\mathrm{P}<0.001)$, SFA $(\mathrm{P}<0.001), \mathrm{n} 6 / \mathrm{n} 3$ ratio $(\mathrm{P}<0.001), \mathrm{AI}(\mathrm{P}<0.001)$ and TI $(\mathrm{P}<0.001)$ had higher values, while $\mathrm{C} 16: 1$ $(\mathrm{P}<0.05), C 18: 3 n 3 \quad(\mathrm{P}<0.01), C 20: 4 n 6 \quad(\mathrm{P}<0.05)$, $\mathrm{C} 20: 5 \mathrm{n} 3(\mathrm{P}<0.001), \mathrm{C} 22: 5 \mathrm{n} 3 \quad(\mathrm{P}<0.01), \mathrm{C} 22: 6 n 3$ $(\mathrm{P}<0.001)$, UFA $(\mathrm{P}<0.001)$, PUFA $(\mathrm{P}<0.05), \mathrm{n} 3$ LC PUFA $(\mathrm{P}<0.001), \mathrm{n} 3(\mathrm{P}<0.001)$ and calculated desaturation indices $(\mathrm{P}<0.001$ for 16:1/16:0, $\mathrm{P}<0.05$ for 18:1/18:0 and 20:4/18:2) had lower ones. Sex had effect only on two fatty acids. Female turkeys had lower $\mathrm{C} 18: 1$ and higher $\mathrm{C} 18: 2$ than male ones $(\mathrm{P}<0.05)$. Breast muscle had higher $\mathrm{C} 17: 1(\mathrm{P}<0.05)$, $\mathrm{C} 20: 3 \mathrm{n} 6 \quad(\mathrm{P}<0.001), \mathrm{C} 20: 4 \mathrm{n} 6 \quad(\mathrm{P}<0.05), \mathrm{C} 22: 5 \mathrm{n} 3$

Table 2. Influence of gender and meat type on chemical composition of breast and thigh meat

\begin{tabular}{|c|c|c|c|c|c|c|c|c|}
\hline & \multicolumn{2}{|c|}{ Sex } & \multicolumn{2}{|c|}{ Type } & \multirow{2}{*}{$\begin{array}{c}\text { Pooled } \\
\text { SD }\end{array}$} & \multicolumn{3}{|c|}{ Interaction } \\
\hline & $\begin{array}{l}\text { Female } \\
(\mathrm{N}=\mathbf{2 0})\end{array}$ & $\begin{array}{l}\text { Male } \\
(\mathbf{N}=\mathbf{2 0})\end{array}$ & $\begin{array}{l}\text { Breast } \\
(\mathrm{N}=\mathbf{2 0})\end{array}$ & $\begin{array}{l}\text { Thigh } \\
(\mathrm{N}=\mathbf{2 0})\end{array}$ & & Sex & Type & $\mathbf{S} \times \mathbf{T}$ \\
\hline Dry matter (DM, \%) & 25.34 & 24.64 & 25.93 & 24.19 & 0.39 & $* * *$ & $* *$ & NS \\
\hline Protein (\%) & 22.96 & 22.08 & 23.71 & 21.52 & 0.50 & $* * *$ & $* * *$ & NS \\
\hline Fat $(\%)$ & 1.31 & 1.51 & 1.14 & 1.64 & 0.11 & $*$ & $* * *$ & $* *$ \\
\hline $\operatorname{Ash}(\%)$ & 1.5 & 1.05 & 1.05 & 1.06 & 0.10 & NS & NS & NS \\
\hline
\end{tabular}

Values are given as means and pooled SD. $* \mathrm{P}<0.05, * * \mathrm{P}<0.01, * * * \mathrm{P}<0.001$. S x T $=$ sex x meat type interaction

The influence of time of storage, sex and meat type on fatty acid profile is presented in Table 3 and Figure 3.
$(\mathrm{P}<0.001), \quad \mathrm{C} 22: 6 \mathrm{n} 3 \quad(\mathrm{P}<0.001), \quad \mathrm{n} 3 \quad$ LC PUFA $(\mathrm{P}<0.001), \mathrm{n} 3(\mathrm{P}<0.01)$ and 20:4/18:2 desaturation index values $(\mathrm{P}<0.01)$ than thigh muscle. The higher

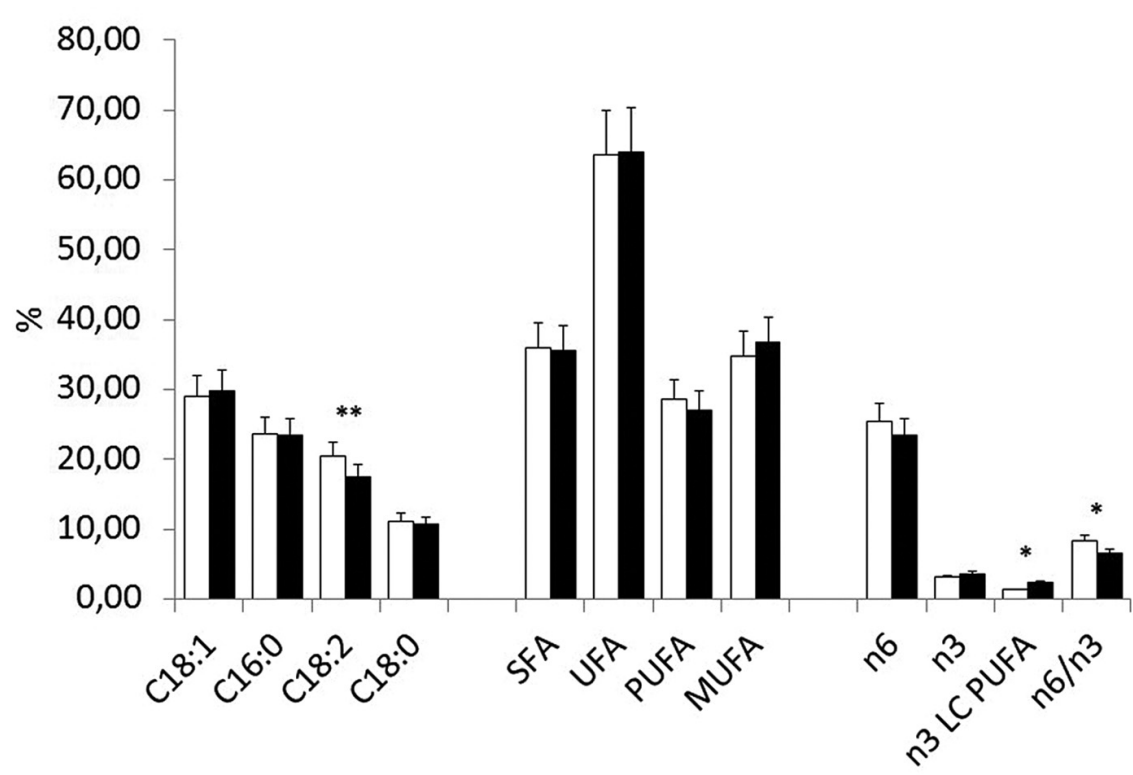

Figure 3. Predominant fatty acids, summarized fatty acid profile and $n 3, n 6$ ratios average values for female and male turkeys (mean and SD), $\square$ Thigh, $\square$ Breast. ${ }^{*} \mathrm{P}<0.05, * * \mathrm{P}<0.01$ 
Meat type, sex and storage time on fatty acid profile of free range Dalmatian turkey

values of $\mathrm{C} 18: 3 \mathrm{n} 3(\mathrm{P}<0.05), \mathrm{C} 20: 0(\mathrm{P}<0.01)$ and n6/n3 ratio $(\mathrm{P}<0.05)$ was observed in thigh muscle in comparison to breast muscle. Interaction of time and sex had impact on C16:1, C20:2, C20:4n6, $\mathrm{C} 22: 5 \mathrm{n} 3$ and 20:4/18:2 index $(\mathrm{P}<0.05)$, whereas time and meat type interaction was found only for FAs $\mathrm{C} 20: 0$ and $\mathrm{C} 20: 5 \mathrm{n} 3(\mathrm{P}<0.05)$.

\section{DISCUSSION}

It is well known that fast-growing birds are mainly used in commercial turkey production, while slow growing birds are selected by farmers for organic and free range production $(16,17)$. Hence, the final weights of turkeys in this study were

Table 3. Influence of gender, meat type and storing time on fatty acid composition of breast ( $m$. pectoralis superficialis) and thigh (m. iliotibialis cranialis)

\begin{tabular}{|c|c|c|c|c|c|c|c|c|c|c|c|c|}
\hline \multirow{2}{*}{$\begin{array}{l}\text { Fatty acids } \\
\text { (\% of total } \\
\text { fatty acids) }\end{array}$} & \multicolumn{2}{|c|}{ Time/ month } & \multicolumn{2}{|l|}{ Sex } & \multicolumn{2}{|c|}{$\begin{array}{l}\text { Interactions } \\
\text { Type }\end{array}$} & \multicolumn{2}{|c|}{ Pooled } & \multirow[b]{2}{*}{ Sex } & \multirow[b]{2}{*}{ Type } & \multirow[b]{2}{*}{$\begin{array}{l}\text { Time X } \\
\text { Sex }\end{array}$} & \multirow[b]{2}{*}{$\begin{array}{l}\text { Time X } \\
\text { Type }\end{array}$} \\
\hline & $\mathbf{0}$ & 6 & Male & Female & Breast & Thigh & SD & Time & & & & \\
\hline C14:0 & 0.74 & 0.70 & 0.69 & 0.75 & 0.71 & 0.73 & 0.08 & NS & NS & NS & NS & NS \\
\hline C14:1 & 0.13 & 0.16 & 0.14 & 0.15 & 0.14 & 0.15 & 0.03 & NS & NS & NS & NS & NS \\
\hline C15:0 & 0.16 & 0.21 & 0.18 & 0.18 & 0.20 & 0.17 & 0.04 & $*$ & NS & NS & NS & NS \\
\hline C15:1 & 0.04 & 0.20 & 0.15 & 0.09 & 0.15 & 0.10 & 0.10 & $* * *$ & NS & NS & NS & NS \\
\hline C16:0 & 23.59 & 27.68 & 25.63 & 25.64 & 25.07 & 26.20 & 2.42 & $* * *$ & NS & NS & NS & NS \\
\hline C16:1 & 5.85 & 4.52 & 5.47 & 4.90 & 5.49 & 4.88 & 1.07 & $*$ & NS & NS & $*$ & NS \\
\hline C17:0 & 0.31 & 0.27 & 0.31 & 0.27 & 0.31 & 0.27 & 0.05 & NS & NS & NS & NS & NS \\
\hline C17:1 & 0.20 & 0.31 & 0.24 & 0.27 & 0.29 & 0.22 & 0.08 & $* *$ & NS & $*$ & NS & NS \\
\hline C18:0 & 10.90 & 13.29 & 12.57 & 11.62 & 11.69 & 12.51 & 1.60 & $* *$ & NS & NS & NS & NS \\
\hline C18:1 & 29.38 & 27.05 & 26.36 & 30.07 & 28.33 & 28.10 & 2.63 & NS & $*$ & NS & NS & NS \\
\hline C18:2 & 19.06 & 18.46 & 19.80 & 17.72 & 18.04 & 19.48 & 1.68 & NS & $*$ & NS & NS & NS \\
\hline $18: 3 n 3$ & 1.49 & 0.91 & 1.20 & 1.19 & 1.02 & 1.38 & 0.40 & $* *$ & NS & $*$ & NS & NS \\
\hline C20:0 & 0.07 & 0.10 & 0.08 & 0.09 & 0.06 & 0.11 & 0.04 & NS & NS & $* *$ & NS & $*$ \\
\hline C20:1n9 & 0.22 & 0.22 & 0.24 & 0.21 & 0.21 & 0.24 & 0.06 & NS & NS & NS & NS & NS \\
\hline C20:2 & 0.12 & 0.19 & 0.17 & 0.14 & 0.16 & 0.15 & 0.05 & $* * *$ & NS & NS & $*$ & NS \\
\hline C20:3n6 & 0.32 & 0.29 & 0.34 & 0.28 & 0.40 & 0.21 & 0.13 & NS & NS & $* * *$ & NS & NS \\
\hline C20:4n6 & 5.10 & 3.80 & 4.49 & 4.40 & 5.20 & 3.70 & 1.46 & $*$ & NS & $*$ & $*$ & NS \\
\hline C20:5n3 & 0.21 & 0.07 & 0.14 & 0.14 & 0.15 & 0.13 & 0.09 & $* * *$ & NS & NS & NS & $*$ \\
\hline C22:5n3 & 0.79 & 0.47 & 0.61 & 0.65 & 0.82 & 0.45 & 0.30 & $* *$ & NS & $* * *$ & $*$ & NS \\
\hline C22:6n3 & 0.87 & 0.47 & 0.62 & 0.73 & 0.92 & 0.42 & 0.37 & $* * *$ & NS & $* * *$ & NS & NS \\
\hline \multicolumn{13}{|c|}{ Summarized fatty acid profile } \\
\hline SFA & 35.77 & 42.26 & 39.47 & 38.56 & 38.04 & 39.98 & 3.75 & $* * *$ & NS & NS & NS & NS \\
\hline UFA & 63.77 & 57.14 & 59.98 & 60.93 & 61.31 & 59.60 & 3.79 & $* * *$ & NS & NS & NS & NS \\
\hline PUFA & 27.84 & 24.47 & 27.21 & 25.11 & 26.54 & 25.77 & 2.87 & $*$ & NS & NS & NS & NS \\
\hline n3 LC PUFA & 1.87 & 1.01 & 1.38 & 1.51 & 1.88 & 1.00 & 0.72 & $* * *$ & NS & $* * *$ & NS & NS \\
\hline MUFA & 35.82 & 32.48 & 32.61 & 35.69 & 34.62 & 33.68 & 2.99 & NS & NS & NS & NS & NS \\
\hline n6 & 24.48 & 22.55 & 24.63 & 22.40 & 23.64 & 23.39 & 2.39 & NS & NS & NS & NS & NS \\
\hline n3 & 3.36 & 1.92 & 2.58 & 2.71 & 2.90 & 2.38 & 0.83 & $* * *$ & NS & $* *$ & NS & NS \\
\hline n6/n3 & 7.46 & 12.14 & 10.43 & 9.17 & 8.80 & 10.80 & 2.83 & $* * *$ & NS & $*$ & NS & NS \\
\hline AI & 0.42 & 0.54 & 0.48 & 0.48 & 0.46 & 0.50 & 0.07 & $* * *$ & NS & NS & NS & NS \\
\hline TI & 0.88 & 1.26 & 1.09 & 1.05 & 1.00 & 1.13 & 0.22 & $* * *$ & NS & NS & NS & NS \\
\hline \multicolumn{13}{|c|}{ Desaturation index } \\
\hline 16:1/16:0 & 0.25 & 0.16 & 0.22 & 0.20 & 0.22 & 0.19 & 0.06 & $* * *$ & NS & NS & NS & NS \\
\hline 18:1/18:0 & 2.95 & 2.09 & 2.28 & 2.77 & 2.59 & 2.45 & 0.58 & $*$ & NS & NS & NS & NS \\
\hline 20:4/18:2 & 0.27 & 0.20 & 0.23 & 0.25 & 0.29 & 0.19 & 0.08 & $*$ & NS & $* *$ & $*$ & NS \\
\hline
\end{tabular}

SFA, Saturated fatty acids; MUFA, monounsaturated fatty acids; LC PUFA, long chain polyunsaturated fatty acid and PUFA, polyunsaturated fatty acids. Values are given as means and pooled $\mathrm{SD}$. $* \mathrm{P}<0.05, * * \mathrm{P}<0.01, * * * \mathrm{P}<0.001, \mathrm{~N}=40$ 
significantly lower than the weight of commercial turkey hybrids. When different genotypes were reared for 25 weeks in free range systems, growth performance was related to the strains with values 5.0 to $6.3 \mathrm{~kg}, 8.2$ to $10.9 \mathrm{~kg}$ and 7.6 to $9.2 \mathrm{~kg}$, for slow growing (American Bronze turkey), fast growing (Hybrid converter) and crosses, respectively (4). Our results for growth performance (Fig. 2) are similar to those for American Bronze, which is a slow growing genotype. The dressing percentage values of indigenous Dalmatian turkey (Table 1) were in accordance with the values for American Bronze turkeys and wild turkeys (18).

As seen also from Table 2, DM, protein and fat contents of raw turkey meat were affected by sex as well as by meat type. Concerning influence of meat type, our results are in accordance to Sarica et al. (4). The aforementioned authors (4) did not see any influence of sex, while we found significant differences between male and female. The significantly higher values for protein and lower values for fat in female birds were observed. These unusual results could be influenced by sexual differences in feed intake in free choice feeding systems, and by hierarchy.

The fatty acid composition of the turkey meat in our trial was characterized by the predominance of $\mathrm{n} 6$ fatty acids, especially C18:2n6 and high $\mathrm{n} 6 /$ n3 ratio (Table 3, Fig. 3). This ratio is an indicator of the balance between the two fatty acid lines entering the food chain (19). A large increase in $n 6$ fatty acids in diet and decrease of EPA and DHA has been associated with inflammatory diseases and obesity (19). Concentrations of C18:2n6 in our trial were significantly lower for female birds, which is in concordance with the results for turkeys in conventional rearing systems (20). The influence of meat type on C18:2n6 was not observed in our study, while other authors observed significant influence of meat type (21).

The most obvious influence on beneficial n3 fatty acids was the time of storage (22). Freezing is one of the most important preservation methods for meat and meat products. Compared with other methods it leads to a minimal loss of quality during long-term storage (6 months) (22). Poultry meat is susceptible to oxidative reactions due to their high concentrations of oxidation catalysts (such as myoglobin and iron) and lipids (23). Lipid oxidation proceeds through a typical self-propagating free radical mechanism where oxygen attack occurs mainly at the allylic positions adjacent to double bonds (24). An increase in time of storage strongly reduced the beneficial long chain polyunsaturated fatty acid (LC PUFA = EPA+DPA+DHA) content, which led to worsening AI and TI (Table 3). The 172 content of n3 PUFA was also influenced by meat type, with lower values of $\mathrm{C} 18: 3 \mathrm{n} 3$ and higher values of LC PUFA in the breast compared to the thighs.

The potential intakes of LC PUFA in our trial would be lower in comparison to modern poultry fed complete feed mixtures (25). Although, it is interesting that in our trial DHA values were higher in comparison to DPA values. Wang et al. (26) reported that 'old fashioned' poultry meat has higher DHA values compared to DPA, while modern poultry has lower DHA values compared to DPA. They speculated that this change may be a consequence of rapid growth in modern birds and the decreased capacity of tissues for DHA synthesis. On the basis of the DHA/DPA ratio, it could be assumed that the LC PUFA content of Dalmatian turkey tissues could be further improved by dietary manipulation. The content of fatty acids in different tissues is influenced by diet, de novo synthesis or bioconversion of linolenic acid (LNA; 18:3n3) and 18:2n6 to corresponding LC PUFA. The lipid deposition in edible tissues is influenced by the efficiency of FA conversion in liver (27). Muscle tissue does not have important desaturation and elongation activity, therefore, muscle DHA/DPA ratio depends on the liver lipogenesis. Future investigations should focus on the differences in liver fatty acid metabolism between modern hybrids and archaic breeds. There is an important difference in diet composition and feed presentation between "old fashioned poultry", which is nowadays generally reared in organic production systems, and modern breeds, which are kept in intensive production. The higher content of LC PUFA in organic poultry tissues is the most frequent consequence of high intakes of green forage, with a higher content of n3 (3). In our trial, experimental Dalmatian turkeys only had access to fresh grass in spring because of the droughts that characterize the local climate during the summer. A commercially feasible feeding program for the local community during the summer period requires a feed that does not contain adequate amounts of LC PUFA or LC PUFA precursors (olive leaves, insects, dry grass and agricultural byproducts). In several investigations LC PUFA content was higher in intensive production compared to organic farming (28). This is the consequence of the fact that high $\mathrm{C} 18: 3 \mathrm{n} 3$ diets in organic production do not always lead to higher LC PUFA contents in edible tissues, because of competition for rate-limiting desaturase enzymes (29). Although green forage rich in $\mathrm{C} 18: 3 \mathrm{n} 3$ is not part of the diet in intensive production systems, high LC PUFA values are caused by dietary manipulations with oils, oil seeds or marine products high in $\mathrm{n} 3$ (22). 
Meat type, sex and storage time on fatty acid profile of free range Dalmatian turkey

\section{CONCLUSION}

The future of Dalmatian turkey breeding lies in a sensitive balance between socially vulnerable local communities and highly demanding consumers concerned for their health. The use of local types of poultry in a breeding program should be encouraged because they are better adapted to the local environment and have been shown to have better disease resistance. Dalmatian turkeys have a well adapted and disease resistant genotype, and in combination with minimal dietary intervention (an increase in LC PUFA precursors and/or use of local vegetation rich in polyphenols) could easily be transformed into a financially feasible product with additional health promoting functions.

\section{REFERENCES}

1. Ferreira, M. M. C., Morgano, M. A., De Queiroz, S. C. D. N., Mantovani, D. M. B. (2000). Relationships of the minerals and fatty acid contents in processed turkey meat products. Food Chem. 69, 259-265. http://dx.doi.org/10.1016/S0308-8146(99)00259-9

2. Baggio, S.R., Miguel, A. M. R., Bragagnolo, N. (2005). Simultaneous determination of cholesterol oxides, cholesterol and fatty acids in processed turkey meat products. Food Chem. 89, 475-484. http://dx.doi.org/10.1016/j.foodchem.2004.05.039

3. Castellini, C., Mugnai, C., Dal Bosco, A. (2002). Effect of organic production system on broiler carcass and meat quality. Meat Sci. 60, 219-225. http://dx.doi.org/10.1016/S0309-1740(01)00124-3

4. Sarica, M., Ocak, N., Turhan, S., Kop, C., Yamak, U. S. (2011). Evaluation of meat quality from 3 turkey genotypes reared with or without outdoor access. Poult. Sci. 90 (6): 1313-1323.

http://dx.doi.org/10.3382/ps.2009-00600 PMid:21597073

5. Starcevic, K., Masek, T., Brozic, D., Filipovic, N., Stojevic, Z. (2014). Growth performance, serum lipids and fatty acid profile of different tissues in chicken broilers fed a diet supplemented with linseed oil during a prolonged fattening period. Vet. Arhiv. 84, 75-84.

6. Carrillo-Dominguez, S., Carranco-Jauregui, M. E., Castillo- Dominguez, R. M., Castro-Gonzalez, M. I., Avila-Gonzalez, E., Perez-Gil, F. (2005). Cholesterol and n-3 and n-6 fatty acid content in eggs from laying hens fed with red crab meal (pleuroncodes planipes). Poult. Sci. 84, 167-172.

http://dx.doi.org/10.1093/ps/84.1.167

PMid:15685957
7. Bou, R., Guardiola, F., Tres, A., Barroeta, A. C., Codony, R. (2004). Effect of dietary fish oil, $\alpha$-tocopheryl acetate, and zinc supplementation on the composition and consumer acceptability of chicken meat. Poult. Sci. 83, 282-292.

http://dx.doi.org/10.1093/ps/83.2.282

PMid:14979581

8. Ekert Kabalin,A., Menčik, S., Ostović, M., Štoković, I., Grgas, A., Horvath, Š., Balenović, T., Sušić, V., Karadjole, I., Pavičić, Ž. (2012). Morphological characteristics of Dalmatian turkey. Mac. J. Anim. Sci. 2, 277-280.

9. Ekert Kabalin, A., Menčik, S., Štoković, I., Horvath, Š., Grgas, A., Balenović, T., Sušić, V., Karadjole, I., Ostović, M., Pavičić, Ž., Marković, D., Marguš, D. (2009). Future of dalmatian turkey - traditional local form of poultry in Croatia. Proc. $60^{\text {th }}$ Annual Meeting of the European Association for Animal Production. Augusut, 24-27, (p. 15), Barcelona, Spain.

10. Santos-Filho, J. M., Morais, S. M., Rondina, D., Beserra, F. J., Neiva, J. N. M., Magalhaes, E. F. (2005). Effect of cashew nut supplemented diet, castration, and time of storage on fatty acid composition and cholesterol content of goat meat. Small Ruminant Res. 57, 51-56.

http://dx.doi.org/10.1016/j.smallrumres.2004.06.016

11. Hahn, G., Spindler, M. (2002). Method of dissection of turkey carcases. World Poul. Sci. J. 58 (1) : 179-197. http://dx.doi.org/10.1079/WPS20020017

12. Jensen, J. F. (1983). Method of dissection of broiler carcasses and description of parts. pp.32 World's Poultry Science Association European Federation Working Group V, Copenhagen.

13. AOAC (1999). Official methods of analysis of the AOAC international. Association of Official Analytical Chemists, Arlington, VA.

14. Folch, J., Lees, M., Stanley, G. H. S. (1957). A simple method for the isolation and purification of total lipides from animal tissues. J. Biol. Chem. 226, 497-509. PMid:13428781

15. Ulbricht, T. L. V., Southgate, D. A. T. (1991). Coronary heart disease: Seven dietary factors. Lancet 338, 985-992. http://dx.doi.org/10.1016/0140-6736(91)91846-M

16. Werner, C., Riegel, J., Wicke, M. (2008). Slaughter performance of four different turkey strains, with special focus on the muscle fiber structure and the meat quality of the breast muscle. Poult. Sci. 87, 1849-1859.

http://dx.doi.org/10.3382/ps.2007-00188

PMid:18753454

17. Sarica, M., Ocak, N., Karacay, N., Yamak, U., Kop, C., Altop, A. (2009). Growth, slaughter and gastrointestinal tract traits of three turkey genotypes under barn and free-range housing systems. Brit. Poult. Sci. 50, 487-494.

http://dx.doi.org/10.1080/00071660903110919 PMid:19735018 
18. Herendy, V., Sütő, Z., Horn, P. (2003). Characteristics of improvement in the turkey production in the last 30 years. Agric. Conspec. Sci. 68, 127-131.

19. Simopoulos, A.P. (2013). Dietary omega-3 fatty acid deficiency and high fructose intake in the development of metabolic syndrome, brain metabolic abnormalities, and non-alcoholic fatty liver disease. Nutrients 5, 2901-2923.

http://dx.doi.org/10.3390/nu5082901

PMid:23896654 PMCid:PMC3775234

20. Komprda, T., Sarmanova, I., Zelenka, J., Bakaj, P., Fialova, M., Fajmonova, E. (2002). Effect of sex and age on cholesterol and fatty acid content in turkey meat. Arch. Geflugelkd. 66, 263-273.

21. Givens, D. I., Gibbs, R. A., Rymer, C., Brown, R. H. (2011). Effect of intensive vs. free range production on the fat and fatty acid composition of whole birds and edible portions of retail chickens in the UK. Food Chem. 127, 1549-1554.

http://dx.doi.org/10.1016/j.foodchem.2011.02.016

22. Soyer, A., Özalp, B., Dalmis, Ü., Bilgin, V. (2010). Effects of freezing temperature and duration of frozen storage on lipid and protein oxidation in chicken meat. Food Chem. 120, 1025-1030.

http://dx.doi.org/10.1016/j.foodchem.2009.11.042

23. Asghar, A., Gray, J. L., Buckley, A. M., Pearson, A. M., Booren, A. M. (1988). Perspectives on warmed-over-flavor. Food Techn. 42, 102-108.

24. Verardo, V., Ferioli, F., Riciputi, Y., Iafelice, G., Marconi, E., Caboni, M. F. (2009). Evaluation of lipid oxidation in spaghetti pasta enriched with long chain n-3 polyunsaturated fatty acids under different storage conditions. Food Chem. 114, 472-477.

http://dx.doi.org/10.1016/j.foodchem.2008.09.074
25. Lo' pez-Ferrer, S., Baucells, M. D., Barroeta, A. C., Galobart, J., Grashorn, M. A. (2001). n-3 Enrichment of Chicken Meat. 2. Use of precursors of long-chain polyunsaturated fatty acids: Linseed oil. Poul. Sci. 80, $753-761$.

http://dx.doi.org/10.1093/ps/80.6.753

26. Givens, D. I., Gibbs, R. A. (2006). Very long chain n-3 polyunsaturated fatty acids in the food chain in the uk and the potential of animal-derived foods to increase intake. Nutr. Bull. 31, 104-110.

http://dx.doi.org/10.1111/j.1467-3010.2006.00554.x

27. Wang, Y., Lehane, C., Ghebremeskel, K., Crawford, M. A. (2010). Modern organic and broiler chickens sold for human consumption provide more energy from fat than protein. Pub. Health Nutr. 13, 400-408.

http://dx.doi.org/10.1017/S1368980009991157

PMid:19728900

28. Castroman, G., Puerto, M. D., Ramos, A., Cabrera, M. C., Saadoun, A. (2013). Organic and conventional chicken meat produced in Uruguay: Colour, ph, fatty acids composition and oxidative status. Am. J. Food Nutr. 1, 12-21.

29. Mašek, T., Starčević, K., Filipović N., Stojević Z., D. Brozić D., Gottstein, Z. , Severin, K. (2014). Tissue fatty acid composition and estimated $\Delta$ desaturase activity after castration in chicken broilers fed with linseed or sunflower oil. Anim. Physiol. Anim. Nut. 98, 384-392.

http://dx.doi.org/10.1111/jpn.12114

PMid:23905627

Please cite this article as: Mauric M., Starcevic K., Mencik S., Ostovic M., Ekert Kabalin A. Influence of meat type, sex and storage time on fatty acid profile of free range Dalmatian turkey. Mac Vet Rev 2016; 39 (2): 167-174. http://dx.doi.org/10.1515/macvetrev-2016-0081 